\title{
I mmunological implications of the use of tyrosine kinase inhibitors in chronic myeloid leukemia
}

\author{
Camila de Souza Rodrigues ${ }^{1}$, Larine Miranda Mendonça ${ }^{1}$, J hony Robison de Oliveira ${ }^{1}$, Marcelo \\ Henrique Napimoga ${ }^{2}$, Maria Theresa Cerávolo Laguna-Abreu ${ }^{3}$ \\ 1. University of Uberaba, Brazil. 2. Laboratory of Immunology and Molecular Biology Institute and Research Center São \\ Leopoldo Mandic, Brazil. 3. Laboratory of Biopathology and Molecular Biology, University of Uberaba, Brazil \\ Correspondence: Maria Theresa Cerávolo Laguna Abreu. Address: Laboratory of Biopathology and Molecular Biology, \\ University of Uberaba Av. Nenê Sabino, 1801, Uberaba, Minas Gerais 38055-500, Brazil. Telephone: 55-343-319-8815. \\ Fax: 55-343-312-6622. E-mail: maria.laguna@uniube.br
}

Received: April 26, 2012

DOI : $10.5430 /$ jhm.v2n3p45
Accepted: June 3, $2012 \quad$ Published: September 1, 2012

URL: http://dx.doi.org/10.5430/jhm.v2n3p45

\section{Abstract}

Background: The treatment of chronic myeloid leukemia (CML) employs drugs known as tyrosine kinase inhibitors (TKIs). Comparative analyses of the effects of different TKIs has shown that these substances can reduce the immunogenicity of leukemic cells, and prejudice anti-tumoral immunity. Once the TKIs differ in terms of their direct influence on cells of the immunological system, the objective of this work was therefore to analyze alterations in the immunological systems of CML patients using different TKI drugs.

Methodology/Principal findings: A review of the literature revealed that imatinib is considered to be the new paradigm for treatment of CML; however, use of this drug can result in inhibition of activation of immune system cells and development of resistance. Second and third generation TKIs can be used in the treatment of patients resistant to imatinib, but can have immunosuppressor effects. Nilotinib is more effective than imatinib in recently-diagnosed patients, however at high doses can induce myelosuppression and diminish cytokine production. Dasatinib was found to induce a rapid full cytogenetic response, with heightened in vivo immune-stimulation, in contrast to an immunosuppression observed in vitro. The mutated T315I phenotype of CML only shows a response to treatment with inhibitors that do not compete with ATP, involving aurora kinases that control mitosis, progression of the cellular cycle, and apoptosis induction. MK0457, which is able to act in the presence of the mutation, presents important bone marrow toxicity, while in small doses danusertib has shown anti-proliferative and pro-apoptotic activity against a wide spectrum of BCR-ABL-positive cells.

Conclusions/Significance: Selection of the most suitable tyrosine kinase inhibitor in patients showing positive to the BCR-ABL mutation requires previous analysis of the phenotype and the influence of the TKI on the immunological system.

\section{Introduction}

Pharmacological control of the activity of the protein tyrosine kinase, whose function involves regulation of the cellular cycle, has been found to be essential in the treatment of chronic myeloid leukemia (CML). This neoplasia, resulting from translocation between chromosomes 9 and 22, t (9; 22) (q34;11), produces the Philadelphia chromosome $\left(\mathrm{Ph}^{+}\right)^{[1,2]}$. The 
presence of this mutated chromosome is responsible for the production of a chimeric protein with elevated tyrosine kinase activity, which activates multiple signaling routes, inducing the proliferation of a clone of malignant myeloid cells in the bone marrow, resulting in an excessive number of these cells ${ }^{[3]}$.

The treatment of CML has employed tyrosine kinase inhibitor (TKI) drugs, which can be classified in relation to the presence or absence of competitive inhibition of adenosine triphosphate (ATP). The inhibitors that are competitive to the ATP binding site can be divided into two subclasses: compounds based on 2-phenylaminopyrimidine, and Src-Abl inhibitors. Inhibitors that do not use the ATP binding site, considered ATP-non-competitive, have been developed to inhibit phosphorylation of the T315I mutation of the BCR-ABL gene, since it has been shown that the competitive inhibitors remain unable to perform this function ${ }^{[4]}$.

Comparative analyses of the effects of different TKIs on CML cells have shown that the drugs can reduce the immunogenicity of leukemic cells, an inevitable collateral effect of inhibition of the BCR-ABL gene, which also prejudices anti-tumoral immunity by directly affecting the intracellular signaling of immunity of effector cells ${ }^{[5]}$. Meanwhile, the effects of these medicines can vary between patients, and with the specific spectrum of kinases on which they act, since the drugs also affect other kinases involved in the activation of immune effector cells ${ }^{[4,5]}$.

The immune system consists of various interconnected components that converge for the elaboration of a response that can be either innate or adaptive, with the latter being the more complex ${ }^{[6]}$. The TKIs differ in terms of their direct influence on cells of the immunological system. Imatinib does not appear to prejudice the cytotoxic activity of NK cells and the production of cytokines, dasatinib seems to reduce the reactivity of NK cells by inhibiting signaling routes and levels of alpha-interferon (IFN- $\alpha$ ), and nilotinib seems to prejudice production of cytokines by the NK cells in a concentration-dependent manner, but not their cytotoxicity ${ }^{[5]}$.

In vitro studies have shown that in the immune system tyrosine kinase inhibitors exert an inhibitory effect by suppressing cell proliferation and the action of NK cells ${ }^{[7]}$; however this notion is not supported by recent work in vivo, since increases in NK and $\mathrm{T}$ cells were observed in patients treated with these drugs ${ }^{[8]}$. Hence, in patients treated with TKIs, modulation of the immunological system can vary depending on the drug used, so that it is important to analyze the therapeutic strategy selected for each patient according to the changes anticipated in the immunological system of the individual. The objective of this work was therefore to analyze, using a review of the literature, alterations in the immunological systems of patients with CML undergoing treatment with different TKI drugs.

\section{ATP-Competitive inhibitors}

\subsection{Compounds based on 2-phenylaminopyrimidine}

Compounds based on 2-phenylaminopyrimidine show high inhibitory potential towards the BCR-ABL gene, acting specifically to block energy transfer to the tyrosine kinase domain, while not inhibiting other tyrosine kinases such as those of the Src kinase family and the T315I mutation of $\mathrm{Abl}^{[4]}$. Imatinib and nilotinib belong to this group of drugs.

\subsubsection{I matinib}

Treatment of patients in the chronic phase of CML with imatinib mesylate (STI-571, Glivec) has shown excellent hematological and cytogenetic responses, as well as few adverse side-effects, and has improved patient survival rates ${ }^{[9,10]}$. This drug acts as an ATP binding site competitive inhibitor, influencing the activity of the tyrosine kinase protein of BCR-ABL and causing the malignant cell to enter into apoptosis. This reduces tumoral proliferation, and also causes the blocking of the various cellular signaling routes activated by the protein. Imatinib has shown long-lasting effects during the chronic phase of $\mathrm{CML}^{[4]}$; however the same results have not been obtained when the treatment was used in more advanced phases of the disease, such as the acute phase and the blast crisis ${ }^{[11]}$. 
Favorable pharmacokinetic characteristics of imatinib include rapid and complete bioavailability via the oral route, and a dose-proportional response ${ }^{[12]}$. Metabolism of imatinib is by means of the cytochrome P450 protein, which catalyzes many reactions involving drug metabolism and synthesis of cholesterol, steroids, and other lipids. CYP3A4 (cytochrome P450, family 3, subfamily A, polypeptide 4) is the isoenzyme most responsible for imatinib metabolism, with smaller contributions from CYP1A2, CYP2D6, CYP2C9, and CYP2C19. The principal metabolite of imatinib, CGP74588, has a similar biological activity, and represents approximately $20 \%$ of the plasma concentration of the original drug ${ }^{[12]}$. Due to the intrinsic variability of the enzymatic activity of the CYP, different responses to imatinib have been observed in patients with CML. Furthermore, other medications that either inhibit or stimulate the CYP3A4 isoenzyme can alter the pharmacokinetic activity of imatinib ${ }^{[12]}$.

Imatinib appears to modulate different anti- and pro-apoptotic proteins of the extrinsic and intrinsic routes of cell apoptosis. Alone or associated with different drugs, such as IFN- $\alpha$ for example, imatinib appears to be able, in vitro, to increase expression of the FasL antigen in leukemic cells, and restore its expression in the immune response effector cells ( $T$ and NK). The increased expression of FasL in leukemic cells seems to contribute to deflagration of the autocrine mechanism of activation of the extrinsic route of apoptosis, leading to the death of the cell. On the other hand, the cytotoxic effector cells might be able to resume their normal function, and contribute to a more effective anti-leukemic immune response ${ }^{[13]}$.

Despite being considered to be the best therapeutic choice in the treatment of CML, this drug can affect the normal function of non-malignant hematopoietic cells, which can induce myelodepression, mainly in the granulocytic series. Patients treated with imatinib can develop neutropenia, trobocytopenia, and anemia as adverse side-effects ${ }^{[9,12,14,15]}$. These effects seem to be correlated with the high plasma imatinib levels often found in patients undergoing treatment ${ }^{[12]}$.

The observed alterations in the erythropoietic series are consistent with drug-resistant hemolytic anemia, as confirmed by Cabera et al. ${ }^{[15]}$ with a positive direct antiglobulin test, and the presence of anti-imatinib antibodies in the serum of the patient. This adverse response has been observed to a greater extent in patients undergoing treatment during the blast crisis phase, compared to those in the chronic phase of the disease ${ }^{[16]}$. Immune thrombocytopenia has been demonstrated by the detection of reactive anti-platelet antibodies using the ELISA technique ${ }^{[15,17]}$.

There is substantial evidence that imatinib can affect immunological responses, especially those mediated by $\mathrm{T}$ lymphocytes ${ }^{[17]}$. The cellular death receptor, Fas, is a key regulator of the immune system. Patients with CML undergoing treatment with imatinib have presented peripheral lymphopenia, as well as reduced activation of CD8 lymphocytes, with potentially deleterious consequences for anti-leukemic responses against this malignant hematological immunogenic disease. Together, these results reveal the role of the Fas receptor in the lymphopenia observed in patients treated with imatinib $^{[18]}$.

In patients with CML, the NK cells, which possess natural antitumoral cytotoxicity, do not recognize their ligands present in the leukemic cells, due to chronic exposure of the NK cell receptor (NKG2D) to the ligands MICA and MICB, which secrete a soluble protein produced by the surface of the tumoral cell, facilitating the escape of the tumor ${ }^{[19]}$. Even though imatinib may not affect the cellular cytotoxicity and cytokine production of the NK cells, it directly influences the reactivity of these cells, reducing the expression of the NKG2D ligands in leukemic cells, hindering the development of the specific immune response and reducing the susceptibility to cytolysis mediated by NK cells ${ }^{[5,7]}$.

Dendritic cells (DC) are recognized to be the most potent antigen-presenting cells capable of initiating and maintaining the primary immune response. They originate from hematopoietic progenitor cells, and are present in peripheral blood and organs of the immune system. Some studies indicate that imatinib can cause reciprocal dendritic cell-NK cell activation, promoting the antitumoral function of the NK cells ${ }^{[20]}$. In patients with CML, the dendritic cells can stimulate the NK cells by increased expression of NKG2D ligands ${ }^{[21]}$. Imatinib seems to prejudice the process of differentiation of dendritic cells 
in vitro, resulting in cells that do not respond to the maturation stimulus, and do not develop either the primary response of $\mathrm{T}$ lymphocytes, or the response of $\mathrm{T}$ lymphocytes to antigens ${ }^{[9,11]}$.

The effects of imatinib on the function and activation of T cells have still not been well defined. Nevertheless, the tyrosine kinases fulfill a vital role in the translation of signals of the T cell receptors (TCR), so that it is conceivable that imatinib could interfere in this process, since the physiological action of $\mathrm{T}$ lymphocytes in response to antigens is controlled by the $\mathrm{T}$ cell receptors ${ }^{[17]}$. Imatinib inhibits the proliferation of $\mathrm{T}$ cells in vitro, as well as the activation of $\mathrm{T}$ lymphocytes mediated by TCR, and the response of CD8+ T lymphocytes to the cytomegalovirus (CMV) and the Epstein-Barr virus ${ }^{\text {[22] }}$. Even though imatinib inhibits the proliferation of T lyphocytes, this cell type does not enter into apoptosis ${ }^{[22]}$.

In CML, monocytes possessing the BCR-ABL gene are an important therapeutic target with respect to the generation of dendritic cells that express a wide spectrum of leukemic antigens. A vaccine based on DC might therefore be able to eliminate persistent leukemic cells in individuals treated with imatinib. Meanwhile, the efficiency of DC-BCR-ABL vaccines depends on the absence of deleterious effects of imatinib on DC function. It has been demonstrated that during cell differentiation, imatinib slightly increases DC apoptosis, while during maturation, in the presence of imatinib, the DC increase expression of the histocompatibility complex (MHC) and co-stimulatory molecules ${ }^{[23]}$. On the other hand, it is possible that the $\mathrm{T}$ lymphocytes may be strongly suppressed by imatinib. For this reason, it has been proposed that an effective DC vaccine against BCR-ABL antigens would require a therapeutic window during which imatinib was absent, to enable a clonal increase of $\mathrm{T}$ cells specific to leukemic antigens ${ }^{[23]}$.

\subsubsection{Nilotinib}

Nilotinib (AMN107, Tasigna) is an aminopyridine compound that presents substantially greater selectivity and affinity for competitive binding with ATP, compared to imatinib ${ }^{[24,25]}$. This drug inhibits the tyrosine kinase activity of BCR-ABL, preventing activation of the mitogenic and anti-apoptotic routes dependent on BCR-ABL ${ }^{[26]}$. Nilotinib shows activity against the majority of the BCR-ABL mutants that possess resistance or intolerance to imatinib; however it does not present activity against the family of Src kinases. Nilotinib has been approved for the treatment of patients in the chronic or accelerated phase of CML that show resistance or intolerance to imatinib, and has provided excellent cytogenetic and hematological responses ${ }^{[25,27,28]}$. These studies confirmed that the drug inhibits phase progression of patients with CML, and is more effective than imatinib in patients recently diagnosed with CML ${ }^{[28]}$.

The concentrations of nilotinib required to inhibit the growth of $\mathrm{Ph}+$ cells in vitro are lower, compared to imatinib, since the latter depends on transporter proteins for its transfer into cells ${ }^{[29]}$. The use of these cells by imatinib could act as a limiting factor for its absorption. The metabolism of nilotinib takes place in the liver by means of the cytochrome P450 enzymes, and can include medicinally relevant interactions ${ }^{[30]}$.

In terms of adverse effects, nilotinib can cause myelosuppression, with the patient presenting anemia, neutropenia, and thrombocytopenia, similar to the results found for imatinib ${ }^{[26,27]}$. Other observed symptoms include cutaneous eruptions, nausea, headaches, itching, fatigue, and increased levels of liver enzymes. These effects have been found to be of light to moderate intensity, and readily resolved by a reduction of the dose and adoption of clinical support measures ${ }^{[26]}$.

Studies in vitro indicate that nilotinib is not able to alter the cytotoxicity of NK cells, since it does not alter the viability of the $\mathrm{CD} 56^{\mathrm{dim}} / \mathrm{CD} 16^{+} \mathrm{NK}$ cells that perform this function. Meanwhile, high doses of nilotinib seem to prejudice the production of cytokines by the CD56 ${ }^{\text {bright }} / \mathrm{CD} 16$ NK cells in cell cultures, by inducing cellular death of this NK cell subtype ${ }^{[5,19]}$. This drug can also negatively modulate expression of the ligands of NK, MICA, and MICB cells, to extents similar to those found for imatinib ${ }^{[5]}$. 


\subsection{Src/ Abl inhibiting compounds}

These compounds are inhibitors of the Src family of kinases, which also show inhibitory properties towards Abl, but are not able to inhibit the T315I mutation of Abl ${ }^{[4]}$. Members of this group of drugs include dasatinib, bosutinib, AP23464, and PD166326.

\subsubsection{Dasatinib}

Dasatinib (BMS354825, Sprycel) is an inhibitor of members of the Src kinase family, such as p56 (Lck), which is involved in various cellular processes in normal cells, and constitutes an integral part of the cascade of cellular signaling. This drug is able to inhibit BCR-ABL, and has been utilized in adult patients with CML who present no response, or intolerance, to imatinib. It is indicated for the treatment of adults during the chronic, accelerated, or blast phases of the disease, and is considered to be a second generation tyrosine kinase inhibitor ${ }^{[8,31]}$.

In clinical studies involving patients recently diagnosed with CML, dasatinib was found to induce a complete cytogenetic response after 12 months, in $98 \%$ of patients. The potency of the drug is therefore much greater than that of imatinib ${ }^{[8,32]}$, and it is active against many mutant domains of BCR-ABL that are resistant to imatinib ${ }^{[33]}$, with the exception of T315I.

Adverse side-effects of dasatinib include diarrhea, vomiting, nausea, gastrointestinal hemorrhaging, cutaneous rashes, and edemas, and there have been reports of pleural and pericardial bleeding ${ }^{[24]}$. Patients treated with dasatinib can present cytopenia. In advanced phase patients, anemia is present in around $60 \%$ of patients undergoing treatment, and neutropenia occurs at a frequency similar to that observed for imatinib ${ }^{[32]}$. However, the use of factors that stimulate granulocyte colonies can help to reverse the latter in patients using dasatinib ${ }^{[31]}$. Rates of thrombocytopenia were $19 \%$ amongst patients that received dasatinib, compared to $10 \%$ for patients receiving imatinib ${ }^{[32]}$.

Dasatinib exhibits inhibitory effects on effector $\mathrm{T}$ cell functions including proliferation, activation of cytokine production, and degranulation. This could be due to inhibition of the Lck activity responsible for transmitting signals from the T cell receptors ${ }^{[34]}$. In vitro studies have also shown that expression of the ligands of NK, MICA, and MICB cells also diminishes with use of this drug, with the reduction in expression being greater than found for imatinib and nilotinib (although differences were not statistically significant) ${ }^{[5]}$.

In contrast to the in vitro data, several studies have found that dasatinib induces immunostimulation, in the form of a marked increase in $\mathrm{T}$ and NK cells ${ }^{[35,36]}$, together with greater cytotoxicity of NK cells in patients with CML. These findings could have implications for treatment, since in 50\% of patients the morphology of the expanded lymphocyte population was indicative of the presence of large granular lymphocytes (LGL), which could have a therapeutic effect on the $\mathrm{Ph}+$ leukemic cells. None of the patients treated with imatinib showed any increases in absolute lymphocyte counts during therapy ${ }^{[8,37]}$.

Many in vitro studies have demonstrated the existence of inhibitory effects of the TKIs on the immunological response ${ }^{[34,38-40]}$. Both imatinib and dasatinib have shown a reversible inhibition of the proliferation of $\mathrm{T}$ cells in vitro, with the effect of dasatinib being greater, probably due to its inhibitory effect on the Src kinases, many of which are important for the activation and proliferation of $\mathrm{T}$ and $\mathrm{B}$ cells ${ }^{[41]}$.

In recent work by Rohon et al. ${ }^{[42]}$, peripheral blood was collected from 88 patients, and 73 samples of bone marrow from individuals diagnosed with CML were analyzed during treatment with imatinib or dasatinib, with evaluation of the different subclasses of immune system cells. At the time the disease was first diagnosed, there were a small proportion of B cells and dendritic cells in the bone marrow, and an elevated number of NKT cells. During treatment with imatinib, all these alterations were normalized, and the immunological pattern was comparable with that of samples obtained from healthy individuals. In the case of dasatinib, the patients were clearly divided into two subgroups, one similar to the healthy controls, and the other presenting immunoactivation characterized by significantly elevated numbers of CD8+, 
NK, and NKT cells in the peripheral blood. The T cells strongly expressed CD57, HLA-DR, and CD45RO, with low levels of expression of CD62L, characteristic of lymphocytes with cytotoxic memory. These findings demonstrate that the TKI can have an immunosuppressor effect in vitro, but a significantly different effect in vivo.

\subsubsection{Bosutinib}

Bosutinib (SKI-606) is (similar to dasatinib) a double inhibitor 4-anilino-3-quinolino-carbonitrile compound that is active against the Src/Abl of CML ${ }^{[43]}$. This drug has shown potent pre-clinical activity against imatinib-resistant cell lines, with the exception of the T315I mutation. It also presents reduced toxicity, since inhibition of c-Kit and the growth factor receptor derived from platelets (PDGF) is minimal ${ }^{[44]}$. The pattern of inhibition of tyrosine kinase shown by bosutinib is similar to that observed for imatinib, although higher concentrations of imatinib are needed for inhibition ${ }^{[45]}$.

Pre-clinical studies suggest that bosutinib causes neutropenia and thrombocytopenia to a lesser extent than dasatinib and nilotinib, and shows an activity profile favorable to a diminution of myelosuppression, since it does not inhibit c-Kit (which has a role in normal hematopoiesis). Bosutinib has been found to be a potent anti-proliferative and pro-apoptotic agent against CML cells in cultures ${ }^{[44]}$.

\subsubsection{AP23464}

AP23464 is a powerful Src/Abl kinase inhibitor whose anti-proliferative activity against CML results from blocking progression of the cellular cycle and inducing apoptosis of Bcr-Abl cells, directly inhibiting Abl activity. AP23464 does not alter the growth of hematopoietic progenitor cells ${ }^{[46]}$, and is ineffective against the T315I mutation ${ }^{[47]}$.

\subsubsection{PD166326}

PD166326 is a pyridopyrimidine compound effective against resistant BCR-ABL mutations. The drug is a potent inhibitor of Src, and has been found to be effective against resistant mutations, since its binding location is different to that of imatinib ${ }^{[48]}$. In vivo studies have revealed that the drug has marked anti-leukemic activity, with a greater reduction in leukocyte counts compared to the use of imatinib ${ }^{[49]}$.

There are other drugs belonging to this family that are at the stage of pre-clinical studies. An example is DCC2036, which appears to present activity against the T315I mutant ${ }^{[24]}$.

\section{Non-ATP-competitive inhibitors}

These inhibitors have distinct mechanisms of action, and show in vitro activity against the mutated T315I phenotype of the BCR-ABL gene. This phenotype shows resistance to various drugs used clinically, including imatinib, nilotinib, and dasatinib ${ }^{[50]}$. The non-competitive inhibitors are small aurora kinase molecules (subtypes $\mathrm{A}, \mathrm{B}$, and $\mathrm{C}$ ) belonging to the family of serine/threonine kinases involved in the control of mitosis, which block progression of the cellular cycle and induce apoptosis. The aurora kinases are exaggeratedly expressed in a variety of tumoral cells, suggesting a role of this family of kinases in tumorigenesis ${ }^{[51]}$. The drugs MK0457 and danusertib are included in this group.

\subsection{MK0457}

MK0457 (VX680) appeared as the first TKI drug with a distinct mechanism that is non-competitive with ATP. It shows activity in vitro against the mutated T315I phenotype of the BCR-ABL gene. MK-0457 is a potent inhibitor of aurora kinase (especially subtypes A and B) in tumor cells, which reduces the phosphorylated histone (H3) in Ser10, resulting in multiple events, including progression of the aberrant cellular cycle and accumulation of polyploid cells containing DNA, which collectively lead to cellular death ${ }^{[51]}$. This drug is already being used in clinical phases I and II in patients with CML or acute lymphocytic leukemia (ALL), and has already shown positive responses ${ }^{[4,52,53]}$. Patients resistant to other drugs (due to the T315I mutation) presented anemia, leukopenia, and thrombocytopenia during treatment with MK0457, with a return to near-normal conditions after the cycle of treatment. When submitted to renewed cycles of treatment, the patients 
again showed the same hematological profiles, which remained constant. The observed bone marrow toxicity was not accompanied by any significant toxicity outside the bone marrow ${ }^{[53]}$.

\subsection{Danusertib}

Danusertib (PHA-739358) is a new aurora kinase drug derived from a molecule called 3-aminopyrazole, which exhibits inhibitory activity against aurora kinases, and is active against the multi-resistant mutant T315I phenotype ${ }^{[54]}$. The use of danusertib represents a promising strategy for the treatment of BCR-ABL-positive leukemias, since it has been shown to have in vitro effects at low concentrations, and to be a potent inhibitor of aurora kinase subtypes A, B, and C. It can therefore be considered to be a pan-aurora kinase inhibitor ${ }^{[50]}$. Danusertib can cause failures in cell division by inducing polyploidy, hence reducing cellular viability. It has also been reported that this drug inhibits phosphorylation of the histone (H3) in Ser10, responsible for chromosome condensation. Inhibition of the H3 histone could be a potential biomarker of the biological activity of the drug ${ }^{[55]}$. Preliminary studies have suggested a synergistic action of danusertib with imatinib, since crystallographic analyses showed that danusertib binds in the ATP-binding domain, while simultaneous treatment using the two drugs resulted in pronounced apoptosis of imatinib-resistant mutations ${ }^{[54]}$. Danusertib has shown strong anti-proliferative and pro-apoptotic activity against a broad spectrum of BCR-ABL-positive cells ${ }^{[50]}$, and is being studied during clinical phase II in patients with CML.

Other drugs, such as AP24534, KW-2449, XL228, and AS703569, are inhibitors of aurora kinase, and are being studied for use in patients with the T315I mutation. AP24534, also known as ponatinib, acts as a BCR-ABL pan-inhibitor, and is at phase II of tests.

\section{Conclusion}

Imatinib is considered to be the new paradigm in CML treatment, and has shown promise in clinical applications. Nonetheless, significant collateral effects, such as myelosuppression and inhibition of activation of cells of the immune system, can occur with use of this drug.

Second/third generation inhibitors of tyrosine kinase are used for the treatment of CML in patients that are resistant to imatinib. The drugs show immunosuppressor effects that operate according to different mechanisms. Nilotinib is more effective than imatinib in patients that have been recently diagnosed with CML; however, the drug can cause myelosuppression and reduced cytokine production when administered at high dosages. Dasatinib has been found to induce a full and rapid cytogenetic response, and is active against many domains of BCR-ABR mutations that are resistant to imatinib, with the exception of T315I. It has shown heightened immunostimulation in vivo, which contradicts immunosuppression observed in vitro. Neither bosutinib nor AP23464 seem to alter normal hematopoiesis.

The mutated T315I phenotype of CML only responds to treatment with inhibitors that are non-competitive to ATP, involving the aurora kinases that control mitosis, progression of the cellular cycle, and induction of apoptosis. MK0457, which can act on the mutated phenotype, shows important bone marrow toxicity. Danusertib is viewed as a new therapeutic drug that can act against the mutation. It can be used in small doses, and shows strong anti-proliferative and pro-apoptotic activity against a wide spectrum of BCR-ABL-positive cells.

It can be concluded that selection of the most suitable tyrosine kinase inhibitor for use in patients testing positive to the BCR-ABL mutation requires previous analysis of its phenotype and of the influence of the different TKIs on the immunological system.

\section{Conflict of interests}

The authors declare that they have no conflict of interest. 


\section{References}

[1] Yan Y, Steinherz P, Klingemann HG, Dennig D, Childs BH, McGuirk J, et al. Antileukemia activity of a natural killer cell line against human leukemias. Clin Cancer Res.1998; 4(11): 2859-68. PMid:9829753

[2] Nowell P. \& Hungerford D. A minute chromosome in human chronic granulocytic leukemia. Science. 1960; $132: 1497$.

[3] Druker BJ, Talpaz M, Resta DJ, Peng B, Buchdunger E, Ford JM, et al. Efficacy and safety of a specific inhibitor of the BCR-ABL tyrosine kinase in chronic myeloid leukemia. N Engl J Med. 2001; 344(14): 1031-7. PMid:11287972 http://dx.doi.org/10.1056/NEJM200104053441401

[4] Lopes N.R. \& Laguna-Abreu MTC. Inibidores de tirosino quinase na Leucemia Mielóide Crônica. Rev. Bras. Hematol. Hemoter. 2009; 31(6): 449-453. http://dx.doi.org/10.1590/S1516-84842009005000089

[5] Salih J, Hilpert J, Placke T, Grünebach F, Steinle A, Salih HR, et al. The BCR/ABL-inhibitors imatinib, nilotinib and dasatinib differentially affect NK cell reactivity. Int J Cancer. 2010; 127(9): 2119-28. PMid:20143399 http://dx.doi.org/10.1002/ijc.25233

[6] Cruvinel WM, Júnior DM, Araújo JAP, Catelan TTT, Souza AWS, Silva NP, et al. Sistema imunitário - Parte I. Fundamentos da imunidade inata com ênfase nos mecanismos moleculares e celulares da resposta inflamatória. Rev Bras Reumatol. 2010; 50(4): 434-61.

[7] Cebo C, Da Rocha S, Wittnebel S, Turhan AG, Abdelali J, Caillat-Zucman S, et al. The decreased susceptibility of Bcr/Abl targets to NK cell-mediated lysis in response to imatinib mesylate involves modulation of NKG2D ligands, GM1 expression, and synapse formation. J Immunol. 2006; 176(2): 864-72. PMid:16393970

[8] Aguilera DG \& Tsimberidou AM. Dasatinib in chronic myeloid leukemia: a review. Ther Clin Risk Manag. 2009 ; 5: $281-289$.

[9] Appel S, Balabanov S, Brümmendorf TH, Brossart P. Effects of Imatinib on Normal Hematopoiesis and Immune Activation. Stem Cells. 2005; 23: 1082-1088. PMid:16140870 http://dx.doi.org/10.1634/stemcells.2005-0069

[10] Hochhaus A, Druker BJ, Larson RA, et al. IRIS 6-year follow-up: Sustained survival and declining annual rate of transformation in patients with newly diagnosed chronic myeloid leukemia in chronic phase (CML-CP) treated with Imatinib. Blood. 2007; 110: 25a.

[11] Vigorito AC. Influência do imatinibe no resultado do TMO e sua eficácia no tratamento da recaída. Rev. bras. hematol. Hemoter. 2008; 30(1): 47-51.

[12] Larson RA, Druker BJ, Guilhot F, O'Brien SG, Riviere GJ, Krahnke T, et al. Imatinib pharmacokinetics and its correlation with response and safety study in chronic-phase chronic myeloid leukemia: a subanalysis of the IRIS. Blood. 2008; 111(8): 4022-4028. PMid:18256322 http://dx.doi.org/10.1182/blood-2007-10-116475

[13] Yin T, Wu YL, Sun HP, Sun GL, Du YZ, Wang KK, et al. Combined effects of As4S4 and imatinib on chronic myeloid leukemia cells and BCR-ABL oncoprotein. Blood. 2004; 104(4): 219-25.

[14] Alvarenga TF, Carvalh LO, Lucenas SB, Dobbins J, Azevedo AA, Fernandez TS, et al. Efeitos adversos e resposta citogenética em pacientes com leucemia mieloide crônica tratados com imatinibe. Rev. Bras. hematol. Hemoter. 2010; 32(2): 116-122. http://dx.doi.org/10.1590/S1516-84842010005000028

[15] Cabrera OMA, Estrada EEE, Martínez EE, Padrón CH, Rodríguez LGR, Cano LI, et al. Reacciones adversas del imatinib como droga de segunda línea en pacientes con leucemia mieloide crônica. Rev. Cubana de Hematol. Inmun. y Hemoter. 2010; 26(1): 223-227.

[16] Flores MAG, Morel IA, Ramirez LM, Flores DSG. Efectos adversos Del mesilato de Imatinib en el tratamiento de la leucemia mieloide cronica. Rev Posgrado Via Cat Med. 2007; 74: 16-9.

[17] Seggewiss R, Loré K, Greiner E, Magnusson MK, Price DA, Douek DC, et al. Imatinib inhibits T-cell receptor-mediated T-cell proliferation and activation in a dose-dependent manner. Blood. 2005; 105: 2473-9. PMid:15572591 http://dx.doi.org/10.1182/blood-2004-07-2527

[18] Legros L, Ebran N, Stebe E, Rousselot P, Rea D, Cassuto JP, et al. Imatinib Sensitizes T-cell Lymphocytes From Chronic Myeloid Leukemia Patients to FasL-induced Cell Death: A Brief Communication. J Immunother. 2012; 35(2): 154-8. PMid:22306903 http://dx.doi.org/10.1097/CJI.0b013e318243f238

[19] Danier ACA, Melo RP, Napimoga MH, Laguna-Abreu MTC. The role of natural killer cells in chronic myeloid leukemia. Rev. Bras. Hematol. Hemoter. 2011; 33(3): 216-220. http://dx.doi.org/10.5581/1516-8484.20110057

[20] Borg C, Terme M, Taïeb J, Ménard C, Flament C, Robert C, et al. Novel mode of action of c-kit tyrosine kinase inhibitors leading to NK cell-dependent antitumor effects. J. Clin. Invest. 2004; 114: 379-388. PMid:15286804

[21] Terme M, Borg C, Guilhot F, Masurier C, Flament C, Wagner EF, et al. BCR/ABL promotes dendritic cell-mediated natural killer cell activation. Cancer Res. 2005; 65(14): 6409-17. PMid:16024645 http://dx.doi.org/10.1158/0008-5472.CAN-04-2675

[22] Dietz AB, Souan L, Knutson GJ, Bulur PA, Litzow MR, Vuk-Pavlovic S. Imatinib mesylate inhibits T-cell proliferation in vitro and delayed-type hypersensitivity in vivo. Blood. 2004; 104(4): 1094-9. PMid:15100154 http://dx.doi.org/10.1182/blood-2003-12-4266 
[23] Boissel N, Delphine R, Vannary T, Nicolas D, Manuel B, Cayuela JM. BCR/ABL Oncogene Directly Controls MHC Class I Chain-Related Molecule A Expression in Chronic Myelogenous Leukemia. The Journal of Immunology. 2006; 176(8): 5108-5116. PMid:16585609

[24] Souza CA. Chronic Myeloid Leukemia - Development of new drugs. Rev. Bras. Hematol. Hemoter. 2008; 30(1): 32-36.

[25] Fei F, Yu Y, Schmitt A, Rojewski MT, Chen B, Greiner J, et al. Effects of nilotinib on regulatory T-cells: the dose matters. Molecular Cancer. 2010; 9(22): 1-10. PMid:20051109

[26] Delamain MT \& Conchon M. Os inibidores de tirosino quinase de segunda geração. Rev. Bras. Hematol. Hemoter. 2008; 30(1): 37-40.

[27] Cortes JE, Jones D, O`Brien S, Jabbour E, Konopleva M, Ferrajoli A. Nilotinib as front-line treatment for patients with chronic myeloid leukemia in early chronic phase. J Clin Oncol. 2010; 28(3): 392-397. PMid:20008621 http://dx.doi.org/10.1200/JCO.2009.25.4896

[28] Saglio G, Kim DW, Issaragrisil S, le Coutre P, Etienne G, Lobo C, et al. Nilotinib versus Imatinib for newly diagnosed chronic myeloid leukemia. N Engl J Med. 2010; 362(24): 2251-9. PMid:20525993 http://dx.doi.org/10.1056/NEJMoa0912614

[29] Rosti G, Palandri F, Castagnetti F, Breccia M, Levato L, Gugliotta G, et al. Nilotinib for the frontline treatment of Ph+ Chronic Myeloid Leukemia. Blood. 2009; 114(24): 4933-4938. PMid:19822896 http://dx.doi.org/10.1182/blood-2009-07-232595

[30] Bitencourt R, Zalcberg I, Louro ID. Imatinib resistance: a review of alternative inhibitors in chronic myeloid leukemia. Rev Bras Hematol Hemoter. 2011; 33(6): 470-475. http://dx.doi.org/10.5581/1516-8484.20110124

[31] Conchon M, Freitas CMBM, Rego MAC, Junior JWRB. Dasatinib - clinical trials and management of adverse events in imatinib resistant/intolerant chronic myeloid leukemia. Rev Bras Hematol Hemoter. 2011; 33(2): 131-139. http://dx.doi.org/10.5581/1516-8484.20110034

[32] Kantarjian H, Shah NP, Hochhaus Andreas, Cortes J, Sandip Shah, Ayala M, et al. Dasatinib versus Imatinib in Newly Diagnosed Chronic-Phase Chronic Myeloid Leukemia. N Engl J Med. 2010; 362: 2260-2270. PMid:20525995 http://dx.doi.org/10.1056/NEJMoa1002315

[33] Fei F, Yu Y, Schmitt A, Rojewski MT, Chen B, Götz M, et al. Dasatinib inhibits the proliferation and function of CD4+CD25+ regulatory T cells. Br J Haematol. 2009; 144(2): 195-205. PMid:19016717 http://dx.doi.org/10.1111/j.1365-2141.2008.07433.x

[34] Schade AE, Schieven GL, Townsend R, Jankowska AM, Susulic V, Zhang R, et al. Dasatinib, a small-molecule protein tyrosine kinase inhibitor, inhibits T-cell activation and proliferation. Blood. 2008; 111(3): 1366-1377.

PMid:17962511 http://dx.doi.org/10.1182/blood-2007-04-084814

[35] Kim DH, Kamel-Reid S, Chang H, Sutherland R, Jung CW, Kim HJ, et al. Natural killer or natural killer/T cell lineage large granular lymphocytosis associated with dasatinib therapy for Philadelphia chromosome positive leukemia. Haematologica. 2009; 94: 135-139. PMid:19066329 http://dx.doi.org/10.3324/haematol.13151

[36] Mustjoki S, Ekblom M, Arstila TP, Dybedal I, Epling-Burnette PK, Guilhot F, et al. Clonal expansion of T/NK-cells during tyrosine kinase inhibitor dasatinib therapy. Leukemia. 2009; 23: 1398-405. PMid:19295545 http://dx.doi.org/10.1038/leu.2009.46

[37] Ravandi F. Dasatinib, an immunomodulator? Blood. 2010; 116(5): 673-4. PMid:20688961 http://dx.doi.org/10.1182/blood-2010-05-283127

[38] Weichsel R, Dix C, Wooldridge L, Clement M, Fenton-May A, Sewell AK, et al. Profound inhibition of antigen-specific T-cell effector functions by dasatinib. Clin Cancer Res. 2008; 14: 2484-91. PMid:18413841 http://dx.doi.org/10.1158/1078-0432.CCR-07-4393

[39] Blake S, Hughes TP, Mayrhofer G, Lyons AB. The Src/ABL kinase inhibitor dasatinib (BMS-354825) inhibits function of normal human T-lymphocytes in vitro. Clin Immunol. 2008; 127: 330-9. PMid:18395492 http://dx.doi.org/10.1016/j.clim.2008.02.006

[40] Chen J, Schmitt A, Chen B, Rojewski M, Rübeler V, Fei F, et al. Nilotinib hampers the proliferation and function of CD8+ T lymphocytes through inhibition of T cell receptor signalling. J Cell Mol Med. 2008; 12: 2107-18. PMid:18194453 http://dx.doi.org/10.1111/j.1582-4934.2008.00234.x

[41] Sefton BM \& Taddie JA. Role of tyrosine kinases in lymphocyte activation. Curr Opin Immunol. 1994; 6: 372-9. http://dx.doi.org/10.1016/0952-7915(94)90115-5

[42] Rohon P, Porkka K, Mustjoki S. Immunoprofiling of patients with chronic myeloid leukemia at diagnosis and during tyrosine kinase inhibitor therapy. Eur J Haematol. 2010; 85(5): 387-98. PMid:20662899 http://dx.doi.org/10.1111/j.1600-0609.2010.01501.x

[43] Golas JM, Arndt K, Etienne C, Lucas J, Nardin D, Gibbons J, et al. SKI-606, a 4-Anilino-3-quinolinecarbonitrile Dual Inhibitor of Src and Abl Kinases,Is a Potent Antiproliferative Agent against Chronic Myelogenous Leukemia Cells in Culture and Causes Regression of K562 Xenografts in Nude Mice. Cancer Research. 2003; 63: 375-381. PMid:12543790 
[44] Cortes JE, Kantarjian HM, Brümmendorf TH, Kim DW, Turkina AG, Shen ZX, et al. Safety and efficacy of bosutinib (SKI-606) in chronic phase Philadelphia chromosome-positive chronic myeloid leukemia patients with resistance or intolerance to imatinib. Blood. 2011; 118(17): 4567-76. PMid:21865346 http://dx.doi.org/10.1182/blood-2011-05-355594

[45] Puttini M, Coluccia AM, Boschelli F, Cleris L, Marchesi E, Donella-Deana A, et al. In vitro and in vivo activity of SKI-606, a novel Src-Abl inhibitor, against imatinib-resistant Bcr-Abl+ neoplastic cells. Cancer Res. 2006; 66(23): 11314-22. PMid:17114238 http://dx.doi.org/10.1158/0008-5472.CAN-06-1199

[46] Corbin AS, Demehri S, Griswold IJ, Wang Y, Metcalf CA 3rd, Sundaramoorthi R, et al. In vitro and in vivo activity of ATP-based kinase inhibitors AP23464 and AP23848 against activation-loop mutants of Kit. Blood. 2005; 106(1): 227-34. PMid:15746079 http://dx.doi.org/10.1182/blood-2004-12-4771

[47] O'Hare T, Pollock R, Stoffregen EP, Keats JA, Abdullah OM, Moseson EM, et al. Inhibition of wild-type and mutant Bcr-Abl by AP23464, a potent ATP-based oncogenic protein kinase inhibitor: implications for CML. Blood. 2004; 104(8): 2532-9. PMid:15256422 http://dx.doi.org/10.1182/blood-2004-05-1851

[48] Von Bubnoff N, Veach DR, van der Kuip H, Aulitzky WE, Sänger J, Seipel P, et al. A cell-based screen for resistance of Bcr-Abl-positive leukemia identifies the mutation pattern for PD166326, an alternative Abl kinase inhibitor. Blood. 2005; 105(4): 1652-9. PMid:15459011 http://dx.doi.org/10.1182/blood-2004-06-2445

[49] Wolff NC, Veach DR, Tong WP, Bornmann WG, Clarkson B, Ilaria RL Jr. PD166326, a novel tyrosine kinase inhibitor, has greater antileukemic activity than imatinib mesylate in a murine model of chronic myeloid leukemia. Blood. 2005; 105(10): 3995-4003. PMid:15657179 http://dx.doi.org/10.1182/blood-2004-09-3534

[50] Gontarewicz A, Balabanov S, Keller G, Colombo R, Graziano A, Pesenti E, et al. Simultaneous targeting of Aurora kinases and Bcr-Abl kinase by the small molecule inhibitor PHA-739358 is effective against imatinib-resistant BCR-ABL mutations including T315I. Blood. 2008; 111(8): 4355-64. PMid:18268096 http://dx.doi.org/10.1182/blood-2007-09-113175

[51] Dai Y, Chen S, Venditti CA, Pei XY, Nguyen TK, Dent P, et al. Vorinostat synergistically potentiates MK-0457 lethality in chronic myelogenous leukemia cells sensitive and resistant to imatinib mesylate. Blood. 2008; 112(3): 793-804. PMid:18505786 http://dx.doi.org/10.1182/blood-2007-10-116376

[52] Soverini S, Iacobucci I, Baccarani M, Martinelli G. Targeted therapy and the T315I mutation in Philadelphia-positive leukemias. Haematologica. 2007; 92(4): 437-9. PMid:17488653 http://dx.doi.org/10.3324/haematol.11248

[53] Giles FJ, Cortes J, Jones D, Bergstrom D, Kantarjian H, Freedman SJ. MK-0457, a novel kinase inhibitor, is active in patients with chronic myeloid leukemia or acute lymphocytic leukemia with the T315I BCR-ABL mutation. Blood. 2007; 109(2): 500-2. PMid:16990603 http://dx.doi.org/10.1182/blood-2006-05-025049

[54] Balabanov S, Gontarewicz A, Keller G, Raddrizzani L, Braig M, Bosotti R, et al. Abcg2 overexpression represents a novel mechanism for acquired resistance to the multi-kinase inhibitor Danusertib in BCR-ABL-positive cells in vitro. PLoS One. 2011; 6(4): e19164. PMid:21541334 http://dx.doi.org/10.1371/journal.pone.0019164

[55] Cohen RB, Jones SF, Aggarwal C, von Mehren M, Cheng J, Spigel DR, et al. A phase I dose-escalation study of danusertib (PHA-739358) administered as a 24-hour infusion with and without granulocyte colony-stimulating factor in a 14-day cycle in patients with advanced solid tumors. Clin Cancer Res. 2009; 15(21): 6694-701. PMid:19825950

http://dx.doi.org/10.1158/1078-0432.CCR-09-1445 